\title{
Vitreous Body Disorder
}

National Cancer Institute

\section{Source}

National Cancer Institute. Vitreous Body Disorder. NCI Thesaurus. Code C45256.

Any disease affecting the vitreous body of the eye. 